\title{
Pengungkapan Sustainability Report dan Kinerja Keuangan
}

\author{
Josua Tarigan ${ }^{*}$, Hatane Semuel $^{1}$ \\ ${ }^{1}$ Fakultas Ekonomi, Universitas Kristen Petra \\ Л. Siwalankerto 121-131, Surabaya 60236 \\ *Penulis korespondensi; email: josuat@petra.ac.id
}

\begin{abstract}
ABSTRAK
Tren penelitian tentang hubungan sustainability report dan kinerja keuangan mulai meningkat di Indonesia, seiring dengan makin meningkatnya jumlah perusahaan yang mempublikasikan sustainability report. Namun sebagian terbesar hasil-hasil penelitian tersebut masih belum konsisten. Penelitian ini bertujuan untuk menguji kembali hubungan antara pengungkapan sustainability report dengan kinerja keuangan. Ada dua hal yang membedakan penelitian ini dari sebelumnya, pertama, penelitian ini menggunakan perusahaan-perusahaan yang secara konsisten melaporkan sustainability report, dan kedua, penelitian ini menggunakan semua ukuran kinerja keuangan yang meliputi asset management, profitability, leverage, liquidity dan market. Sampel yang digunakan sebanyak 54 pengamatan yang berasal dari perusahaan-perusahaan yang secara konsisten melaporkan sustainability report selama periode 2009-2011. Hasil pengujian menunjukkan bahwa dimensi ekonomi (EC) dari sustainability report tidak berpengaruh terhadap kinerja keuangan, sedangkan dua dimensi lainnya yaitu lingkungan (EN) dan sosial (SO) berpengaruh negatif terhadap kinerja keuangan.
\end{abstract}

Kata kunci: Sustainability report, dimensi ekonomi, dimensi sosial, dimensi lingkungan, kinerja keuangan.

\begin{abstract}
Research trends regarding sustainability report begin to increase gradually in Indonesia, as well as the increasing of companies that publish sustainability report. However, many of these studies still show inconsistent results. The aim of this study is to reexamine the relationship between sustainability report disclosure and financial performance. There are two things that distinguish this research from the previous ones. Firstly, this research uses companies that consistently publish sustainability report and secondly, this study uses all of measures of financial performance, namely: the size of the asset management, profitability, leverage, liquidity and market. Samples consist of 54 firm-years, which is derived from the companies that consistently publish sustainability reporting for the period 2009-2011. The results indicate that the economic dimension (EC) of the sustainability report has no effect on the financial performance, while the other two dimensions, namely the environment (EN) and social (SO) negatively affect financial performance.
\end{abstract}

Keywords: Sustainability report, economic dimension, social dimension, environmental dimension, financial performance.

\section{PENDAHULUAN}

Pengungkapan laporan keberlanjutan (sustainability report) telah berkembang dan menjadi salah satu hal yang penting bagi setiap organisasi (Ernst and Young, 2013). Sustainability report menjadi media bagi perusahaan untuk menginformasikan kinerja organisasi dalam aspek ekonomi, sosial dan lingkungannya kepada seluruh pemangku kepentingan (stakeholders). Banyak organisasi sudah mulai beralih dari cara tradisional yang hanya melaporkan aspek keuangan, berubah ke arah yang lebih modern, yakni melaporkan semua aspek, baik keuangan maupun nonkeuangan (dimensi sosial dan lingkungan) kepada para pemangku kepentingan. Dalam penelitian yang 
dilakukan oleh Dhaliwal et al. 2011 (dalam Ernst and Young, 2013) terhadap 7000 sustainability report, ditemukan bawah sustainability report banyak digunakan organisasi dalam memprediksi nilai pasar sebuah organisasi. Hal ini disebabkan karena sustainability report tidak saja memuat informasi kinerja keuangan tetapi juga informasi non-keuangan. Lebih jauh penelitian yang dilakukan oleh oleh Tomo (2011) menunjukkan ada kesenjangan atas nilai perusahaan jika hanya memperhatikan aspek keuangan saja. Penelitian yang dilakukan atas nilai pasar organisasi menunjukkan pergerakan yang cukup signifikan, dimana nilai pasar perusahaan tahun 1975 sebanyak 83\% di tentukan oleh aspek keuangan dan 17\% aspek non-keuangan. Hal ini telah berubah drastis dengan data tahun 2009, di mana nilai pasar organisasi bisnis ditentukan hanya $19 \%$ saja aspek keuangan dan sisanya $81 \%$ adalah aspek non-keuangan

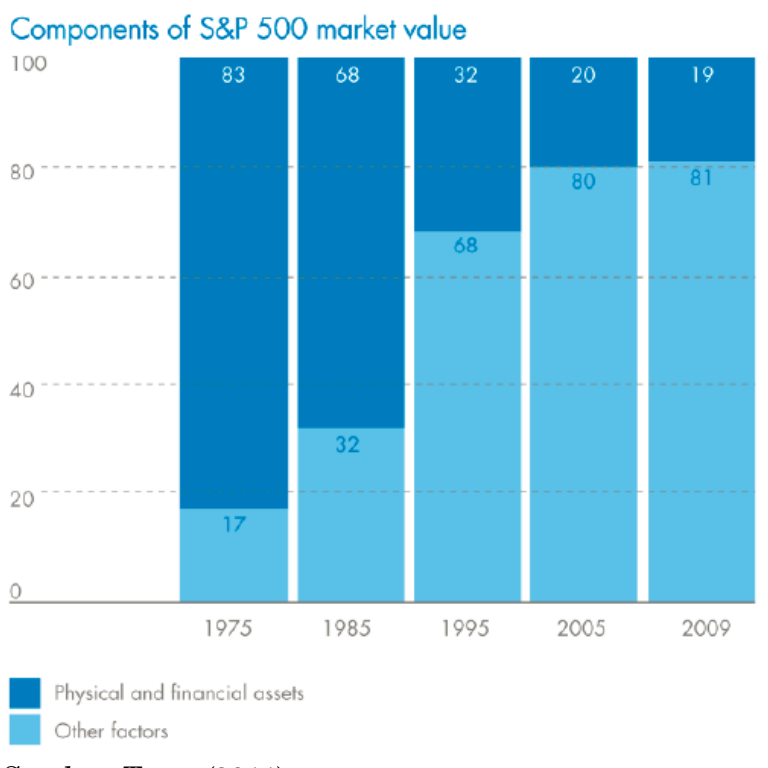

Sumber: Tomo (2011)

Gambar 1. Tren proporsi antara aset keuangan dan non-keuangan sejak tahun 1975-2009

Aspek non-keuangan ini yang memungkinkan perusahaan bisa menghasilkan kinerja yang berkesinambungan (sustainable performance). Sustainable performance merupakan kinerja yang dihasilkan dengan menyeimbangkan ketiga aspek berupa people-planet-profit, yang dikenal dengan konsep Triple Bottom Line (TBL). Sustainability report merupakan praktek pengukuran, pengungkapan dan upaya akuntabilitas dari sustainability activities yang bertujuan untuk tercapainya sustainable development (Global Reporting Initiative, 2011). Perusahaan yang mempertimbangkan pengembangan yang berkelanjutan (sustainable development) akan dapat meningkatkan nilai perusahaan karena dukungan yang diperoleh dari stakeholder baik internal maupun eksternal, seperti konsumen, karyawan, investor, regulator, pemasok maupun kelompok lainnya. Kemampuan perusahaan untuk mengkomunikasikan kegiatan dan kinerja sosial dan lingkungan secara efektif dalam sustainability report dinilai penting untuk keberhasilan jangka panjang, kelangsungan hidup dan pertumbuhan organisasi (KPMG, 2008).

Menurut Elkington (1997), perusahan memiliki tanggung jawab atas dampak positif maupun negatif yang ditimbulkan terhadap aspek ekonomi, sosial dan lingkungan. Dalam bahasa yang sama juga diungkapkan oleh majalah Investor, dimana perusahaan perlu membangun hubungan baik dengan semua stakeholder, tidak sekadar menjaga hubungan dengan pemegang saham (shareholder) dan memberi bantuan sosial, tetapi perusahaan juga harus membina hubungan dengan konsumen, pemerintah, dan masyarakat luas (Menjaga kesinambungan, 2013).

Di Indonesia, publikasi sustainability report sudah mulai menjadi tren, salah satunya didorong oleh adanya pemberian penghargaan tahunan atas sustainability report yang diinisiasi oleh lembaga National Center for Sustanaibility Reporting (NCSR). Selain itu, menguatnya tuntutan stakeholders mendorong perusahaan untuk memberikan informasi yang transparan, akuntabel, dan praktik tata kelola perusahaan yang baik. Penelitian terdahulu yang dilakukan tekait sustainability report sebagian besar hanya berfokus untuk melihat dampak sustainability report terhadap indikator kinerja keuangan tertentu saja seperti penelitian yang di lakukan oleh Soelistyoningrum \& Prastiwi (2011); Reddy \& Gordon (2010) dan Bartlett (2012). Oleh karena itu, penelitian ini akan menggunakan semua indikator kinerja keuangan yang ada, dalam rangka memperkaya model penelitian tentang sustainability report. Selain itu penelitian ini juga melakukan kajian yang lebih mendalam atas 54 pengamatan yang ada, dengan melakukan uji beda untuk melihat lebih jauh implikasi dari kondisi organisasi yang melaporkan sustainability report.

\section{Stakeholders Theory}

Stakeholder theory merupakan salah satu teori utama yang banyak digunakan untuk mendasari penelitian tentang sustainability report. Salah satu pendukung teori ini adalah Donaldson dan Preston (1995) yang berpendapat bahwa stakeholder theory memperluas tanggungjawab organisasi kepada seluruh pemangku kepentingan tidak hanya kepada investor atau pemilik. Pemikiran awal tentang stakeholders theory 
dicetuskan oleh Freeman (1984). Freeman (1984), mendefinisikan stakeholders sebagai kelompok yang secara siginifikan mempengaruhi kesuksesan dan kegagalan sebuah organisasi. Secara singkat, Freeman menggambarkan stakeholders theory sebagai respon manajer kepada lingkungan bisnis yang ada (Laplume, Sonpar and Litz, 2008).

Perusahaan harus menjaga hubungan dengan para pemangku kepentingan dengan mengakomodasi keinginan dan kebutuhan yang ada, terutama para pemangku kepentingan yang mempunyai kekuatan terhadap ketersediaan sumber daya yang digunakan untuk aktivitas operasional perusahaan, seperti tenaga kerja, pelanggan dan pemilik (Ghozali dan Chariri, 2007). Oleh karena itu kelangsungan hidup organisasi bergantung pada dukungan para pemangku kepentingan sehingga aktivitas perusahaan adalah untuk mencari dukungan tersebut. Salah satu strategi untuk menjaga hubungan dengan para pemangku kepentingan perusahaan adalah dengan mengungkapkan sustainability report yang meliputi aspek ekonomi, sosial dan lingkungan. Pengungkapan sustainability report diharapkan dapat memenuhi keinginan dari para pemangku kepentingan sehingga akan menghasilkan hubungan yang harmonis antara perusahaan dengan para pemangku kepentingan, sehingga organisasi dapat mencapai keberlanjutan dimasa akan datang.

\section{Legitimacy Theory}

Teori kedua yang mempengaruhi pemikiran laporan berkelanjutan adalah teori legitimasi. Kedua teori baik legitimacy theory dan stakeholders theory merupakan teori yang menjelaskan motivasi para manajer atau organisasi untuk melakukan pengungkapan laporan berkelanjutan. Jika teori stakeholders dimotivasi oleh pertanggungjawaban kepada para pemangku kepentingan, maka teori legitimasi menggunakan motivasi untuk mendapatkan pengesahan atau penerimaan dari masyarakat (Laan, 2009). Teori legitimasi menegaskan bahwa perusahaan terus berupaya untuk memastikan bahwa mereka beroperasi dalam bingkai dan norma yang ada dalam masyarakat atau lingkungan dimana perusahaan berada, dimana mereka berusaha untuk memastikan bahwa aktifitas mereka (perusahaan) diterima oleh pihak luar sebagai suatu yang sah (Deegan, 2004). Ghozalidan Chariri (2007) menyatakan bahwa hal yang melandasi teori legitimacy adalah kontrak sosial yang terjadi antara perusahaan dengan masyarakat dimana perusahaan beroperasi. Shocker dan Sethi dalam Ghozali dan Chariri (2007) memberikan penjelasan tentang konsep kontrak sosial, bahwa semua organisasi memiliki kontrak sosial, baik eksplisit maupun implisit, dimana kelangsungan hidup dan pertumbuhan organisasi tergantung pada apa yang dapat dikontribusikan oleh organisasi kepada masyarakat luas. Apabila organisasi memberikan kontribusi sosial, maka keberadaan perusahaan dan aktivitas yang dilakukan mendapat "status" atau "restu" dari masyarakat atau lingkungan dimana perusahaan tersebut beroperasi.

Teori legitimasi mendorong perusahaan untuk meyakinkan bahwa aktivitas dan kinerjanya dapat diterima oleh masyarakat. Laporan aktivitas tanggungjawab sosial dan lingkungan perusahan yang dituangkan dalam sustainability report dapat digunakan oleh perusahaan untuk membuktikan bahwa perusahaan telah menjalankan tanggung jawab sosial. Hal ini sebagai upaya agar keberadaan organisasi dapat diterima oleh masyarakat. Legitimasi dari masyarakat merupakan salah satu sumber daya operasional yang penting bafi perusahaan.

\section{Sustainability report}

Sustainability report memiliki definisi yang beragam, menurut Elkington (1997),sustainability report berarti laporan yang memuat tidak saja informasi kinerja keuangan tetapi juga informasi non keuangan yang terdiri dari informasi aktivitas sosial dan lingkungan yang memungkinkan perusahaan bisa bertumbuh secara berkesinambungan (sustainable performance). Saat ini implementasi sustainability report di Indonesia didukung oleh aturan pemerintah seperti UndangUndang Perseroan Terbatas (PT) nomer 40 tahun 2007. Praktek pelaporan aktivitas tanggung jawab sosial dan lingkungan yang diungkapkan melalui sustainability report membutuhkan pedoman. Salah satu pedoman yang dapat digunakan adalah Global Reporting Initiative (GRI). Di Indonesia, pedoman ini digunakan oleh NCSR, sebagai lembaga independen yang secara berkala memberikan penilaian pengungkapan sustainability report yang disampaikan perusahaan-perusahaan. Manfaat sustainability report berdasarkan pada kerangka GRI (2011) adalah sebagai berikut:

1. Sebagai benchmark kinerja organisasional dengan memperhatikan hukum, norma, undang-undang, standar kinerja, dan prakarsa sukarela;

2. Mendemostrasikan komitmen organisasional untuk sustainable development, dan

3. Membandingan kinerja organisasional setiap waktu.

Sustainability report juga dapat digunakan oleh institusi pemerintah misalnya dari pihak 
kementerian lingkungan untuk membuat penilaian atas kinerja perusahaan terhadap lingkungan dalam setiap pelaporan organisasi. Seperti halnya di Indonesia, peraturan dalam pengungkapan CSR dapat ditemukan dalam aturan yang dikeluarkan oleh Undang-Undang Nomor 40 tahun 2007 tentang Perseroan Terbatas (PT), khususnya pasal 74.

Sustainability report dalam pedoman GRI versi 3.1 terbagi menjadi tiga dimensi, yaitu aspek Ekonomi-Economics (EC), Lingkungan-Environment (EN) dan Sosial. Aspek sosial terdiri dari empat sub-dimensi yaitu: Tenaga Kerja - Labor (LA), Hak Asasi Manusia-Human Rights (HR), Masyarakat - Society (SO), dan Tanggung Jawab Produk - Product Responsibility (PR). Penelitian ini menggunakan GRI versi 3.1, belum menggunakan versi 4.0, hal ini disebabkan karena semua sampel penelitian ini masih menggunakan sustainability report dengan standar GRI versi 3.1

\section{Kinerja Keuangan}

Menurut Ross et al. (2003), kinerja keuangan dapat dicerminkan melalui analisis rasio-rasio keuangan suatu perusahaan. Lebih jauh Ross menjelaskan ada lima dimensi rasio keuangan yang digunakan dalam mengukur kinerja keuangan organisasi:

1. Dimensi Manajemen Aset yang diukur dengan menggunakan lima indikator, yaitu: Inventory Turnover ratios, Receivables Turnover ratios, Net Working Capital Turnover ratios, Fixed Asset Turnover ratios, Total Asset Turnover ratios.

2. Dimensi Profitabilitas yang diukur dengan menggunakan tiga indikator, yaitu: Profit Margin, ROA (Return on Assets) dan ROE (Return on Equity).

3. Dimensi Leverage yang diukur dengan menggunakan tiga indikator, yaitu: Debt Equity Ratio (DER), Time Interest Earned (TIE) dan Cash Coverage.

4. Dimensi Likuiditas yang diukur dengan menggunakan tiga indikator, yaitu: Current Ratio, Quick Ratio dan Cash Ratio.

5. Dimensi Pasar yang diukur dengan menggunakan dua indikator, yaitu: Price Earning Ratio (PER) dan Market Book Value (MBV).

Penelitian terdahulu terkait laporan berkelanjutan dan kinerja keuangan, menggunakan ukuran kinerja laporan berkelanjutan (Kocmanova et al. 2012). Peneliti tersebut menambahkan elemen baru sebagai ukuran laporan berkelanjutan yakni elemen corporate governance. Beberapa penelitian terdahulu lainnya terkait dengan lapor- an berkelanjutan dan kinerja keuangan, secara lengkap disajikan pada Tabel 1.

\section{Hipotesis}

Informasi yang tercantum dalam laporan berkelanjutan dimensi ekonomi (EC) dapat meyakinkan potensi sumber daya modal yang kompetitif tingkat resiko rendah kepada stakeholder. Penelitian terbaru yang dipublikasikan oleh Ernst \& Young (2013) mengatakan bahwa investor lebih memilih untuk berinvestasi di organisasi yang transparan dalam hal keakuratan peramalan dan analisis, serta informasi yang diberikan memiliki asimetri lebih rendah. Dengan adanya kepercayaan dari investor maupun kreditor, maka jumlah pendanaa pada perusahaan akan meningkat. Pendaanan ini dapat digunakan oleh organisasi untuk meningkatkan kinerja keuangan yang ada. Lebih jauh penelitian yang dilakukan oleh Cahyandito (2010) Pengungkapan kinerja ekonomi dalam sustainability report akan meningkatkan transparansi perusahaan yang berdampak pada peningkatan kepercayaan investor dan kinerja keuangan. Berdasarkan kajian tersebut dapat di rumuskan hipotesis pertama seperti dibawah ini. H1: Ada pengaruh antara pengungkapan sustainability report dimensi ekonomi (EC) dengan kinerja keuangan.

Publikasi terbaru dari Ernst \& Young (2013) menemukan bahwa kualitas pengungkapan lingkungan (EN) dengan nilai perusahaan memiliki hubungan yang positif. Kemampuan perusahaan untuk mengkomunikasikan kegiatan lingkungan kepada stakeholders perusahaan dinilai penting untuk meningkatkan reputasi dan kepercayaan stakeholder, termasuk konsumen yang dapat mengakibatkan peningkatan pendapatan perusahaan (Ernst \& Young, 2013). Disisi lain, aktivitas keberlanjutan juga merupakan salah satu upaya organisasi untuk berkontribusi terhadap sustainable development. Sustainable development bertujuan untuk pemenuhan kebutuhan manusia dan meningkatkan kualitas kehidupan manusia. Pemanfaatan sumber daya alam yang terdapat di lingkungan harus dilakukan dengan efisien dan bertangung jawab, agar tidak mempengaruhi kemampuan generasi mendatang untuk memenuhi kebutuhannya. Oleh karena itu dapat dikatakan sustainable development dilakukan agar sumber daya alam dapat digunakan dengan efisien untuk masa kini dan masa depan. Jadi, sustainable development yang dilaporkan dalam laporan berkelanjutan dimensi lingkungan (EN) memiliki hubungan dengan kinerja keuangan organisasi. Hal ini juga diungkapkan oleh Ngwakwe (2008) yang melihat 
Tabel 1. Ringkasan Penelitian Terdahulu

\begin{tabular}{|c|c|c|c|}
\hline No. Judul Penelitian & Variabel & Uji statitik & Hasil \\
\hline $\begin{array}{l}\text { 1. Pengaruh Pengungkapan } \\
\text { Sustainability Report } \\
\text { Terhadap Kinerja } \\
\text { Keuangan Perusahaan } \\
\text { Soelistyoningrum, J.N., \& } \\
\text { Prastiwi, A. (2011) } \\
\end{array}$ & $\begin{array}{l}\text { Independent: SR } \\
\text { Dependent: Profitabilitas, } \\
\text { Likuiditas, } \\
\text { Rasio pembayaran dividen. }\end{array}$ & Regressin analysis & $\begin{array}{l}\text { Pengungkapan SR berpengaruh } \\
\text { signifikan positif terhadap ROA dan } \\
\text { CR, sedangkan untuk variabel } \\
\text { dependen DPR, pengungkapan SR } \\
\text { tidak memiliki pengaruh signifikan. }\end{array}$ \\
\hline $\begin{array}{l}\text { 2. The Relation Between } \\
\text { Sustainability Performance } \\
\text { And Financial } \\
\text { Performance Of Firms. } \\
\text { Weber, O., Koellner, T., } \\
\text { Habegger, D., Steffensen, } \\
\text { H., \& Ohnemus, P. (2005) }\end{array}$ & $\begin{array}{l}\text { Independent: SR } \\
\text { Dependent: EBITDA, ROA, } \\
\text { dan ROE. }\end{array}$ & $\begin{array}{l}\text { Binary logistic } \\
\text { regression. }\end{array}$ & $\begin{array}{l}\text { Terdapat korelasi positif antara } \\
\text { kegiatan keberlanjutan, dampak } \\
\text { pada sustainable development dan } \\
\text { kinerja keuangan perusahaan. SR di } \\
\text { bidang lingkungan, sosial dan } \\
\text { ekonomi mengakibatkan kinerja } \\
\text { yang baik sehubungan dengan } \\
\text { dampak keberlanjutan di tiga } \\
\text { bidang. Namun, hasil ini tidak } \\
\text { berlaku untuk bidang tata kelola } \\
\text { perusahaan. }\end{array}$ \\
\hline $\begin{array}{l}\text { 3. The Effect of Sustainability } \\
\text { Reporting on Financial } \\
\text { Performance: An Empirical } \\
\text { Study Using Listed } \\
\text { Companies. Reddy \& } \\
\text { Gordon (2010) }\end{array}$ & $\begin{array}{l}\text { Independent: SR } \\
\text { Dependent: stock return } \\
\text { data-abnormal return }\end{array}$ & $\begin{array}{l}\text { Cross-sectional } \\
\text { dummy regression } \\
\text { analysis. }\end{array}$ & $\begin{array}{l}\text { SR signifikan secara statistik dalam } \\
\text { menjelaskan abnormal return bagi } \\
\text { perusahaan Australia, tetapi tidak } \\
\text { untuk perusahaan New Zealand. } \\
\text { Hasil analisis gabungan bagi kedua } \\
\text { negara mendukung pandangan } \\
\text { bahwa faktor-faktor kontekstual } \\
\text { jenis industri berdampak signifikan } \\
\text { pada abnormal return perusahaan } \\
\text { pelaporan. }\end{array}$ \\
\hline $\begin{array}{l}4 \text { The Effect of Corporate } \\
\text { Sustainability Reporting } \\
\text { on Firm Valuation. } \\
\text { Bartlett (2012) }\end{array}$ & $\begin{array}{l}\text { Independent: SR } \\
\text { Dependent: } \\
\text { market value-net income } \\
\text { before extraordinary items, } \\
\text { book value, and corporate } \\
\text { sustainability level }\end{array}$ & $\begin{array}{l}\text { Cross section } \\
\text { regression, analisis } \\
\text { panel. }\end{array}$ & $\begin{array}{l}\text { Aspek sustainability report } \\
\text { lingkungan dan sosial signifikan } \\
\text { berkorelasi positif dengan nilai } \\
\text { pasar. Perusahaan sustain } \\
\text { merupakan faktor yang sangat } \\
\text { signifikan bagi nilai pasar di industri } \\
\text { farmasi dan industri otomotif. }\end{array}$ \\
\hline $\begin{array}{l}\text { 5. The relationship between } \\
\text { sustainability practices and } \\
\text { financial performance of } \\
\text { construction companies. } \\
\text { Siew, R.Y.J., Balatbat \& } \\
\text { Carmichael (2013) }\end{array}$ & $\begin{array}{l}\text { Independent: SR } \\
\text { Dependent: Profitabilitas } \\
\text { EquityValuation }\end{array}$ & $\begin{array}{l}\text { Cross-sectional dan } \\
\text { nalisis varian. }\end{array}$ & $\begin{array}{l}\text { Mayoritas perusahaan konstruksi } \\
\text { tingkat pelaporannya rendah, } \\
\text { sedangkan perusahaan konstruksi } \\
\text { yang mengeluarkan laporan non- } \\
\text { keuangan sebagian besar } \\
\text { mengungguli mereka yang tidak di } \\
\text { sejumlah rasio keuangan, meskipun } \\
\text { hubungan antara keuangan skor } \\
\text { kinerja dan ESG tidak kuat. }\end{array}$ \\
\hline $\begin{array}{l}\text { 6. Sustainability Strategies of } \\
\text { Leading Global Firms and } \\
\text { Their Financial Perfor- } \\
\text { mance: A Comparative } \\
\text { Case Based Analysis. } \\
\text { Movassaghi \& } \\
\text { Bramhandkar (2012) }\end{array}$ & $\begin{array}{l}\text { Independent: sustainability } \\
\text { scores-KLD. } \\
\text { Dependent: profitabilitas } \\
\text { Market valuasi }\end{array}$ & $\begin{array}{l}\text { Correlation analysis } \\
\text { dan regression } \\
\text { analysis. }\end{array}$ & $\begin{array}{l}\text { Sustainability performance tidak } \\
\text { mempengaruhi profitabilitas } \\
\text { perusahaan sampel yang berasal } \\
\text { dari sektor industri dan negara yang } \\
\text { berbeda. Perusahaan sustainability } \\
\text { tidak melanggar fungsi utama untuk } \\
\text { meningkatkan nilai pemegang } \\
\text { saham yang ditentukan oleh return } \\
\text { (keuntungan) dan risiko. }\end{array}$ \\
\hline $\begin{array}{l}\text { 7. A Study of Publicly-Held } \\
\text { U.S. Corporations on the } \\
\text { Effects of Sustainability } \\
\text { Measures on Financial } \\
\text { Performance, Utilizing a } \\
\text { Modified Regression } \\
\text { Discontinuity Model. } \\
\text { Welter (2011) }\end{array}$ & $\begin{array}{l}\text { Independent: sustainability } \\
\text { scores-KLD. } \\
\text { Dependent: Total Aset, } \\
\text { Laba Bersih, ROA }\end{array}$ & $\begin{array}{l}\text { Analisis regresi } \\
\text { linier, model regresi } \\
\text { diskontinuitas } \\
\text { dimodifikasi. }\end{array}$ & $\begin{array}{l}\text { Pada industri spesifik, sustainability } \\
\text { berhubungan signifikan terhadap } \\
\text { kinerja keuangan perusahaan. }\end{array}$ \\
\hline
\end{tabular}


bahwa ada hubungan signifikan antara kinerja lingkungan dengan kinerja keuangan. Berdasarkan kajian tersebut dapat di rumuskan hipotesis pertama seperti dibawah ini.

H2: Ada pengaruh antara pengungkapan sustainability report dimensi lingkungan (EN) dengan kinerja keuangan

Sama halnya dengan aktivitas terkait lingkungan (EN), aktivitas sosial (SO) juga membutuhkan investasi aset untuk melaksanakan sustainability activities dalam bidang aspek sosial. Sustainability activities ini dilakukan tidak hanya kepada para pemangku kepentingan eksternal, tetapi juga internal. Oleh sebab itu dampak pengungkapan laporan berkelanjutan dalam bidang sosial (SO) pasti dapat dirasakan oleh seluruh para pemangku kepentingan organisasi (KPMG, 2008). Dengan melaksanakan dan melaporkan tanggung jawab sosial (SO) terhadap para pemangku kepentingan tidak hanya dapat meningkatkan harga saham rata-rata perusahaan, tetapi juga dapat meningkatkan kesejahteraan dan loyalitas karyawan, menurunkan tingkat perputaran karyawan sehingga dapat berujung pada meningkatnya produktivitas perusahaan (Ernst \& Young, 2013). Oleh karena itu pengungkapan laporan berkelanjutan dalam aspek sosial (SO) penting dan berpengaruh terhadap kinerja keuangan organisasi. Sama halnya dengan penelitian yang dilakukan oleh Burhan dan Wiwin (2012) menunjukkan bahwa kinerja dimensi sosial (SO) berdampak signifikan terhadap kinerja keuangan. Berdasarkan kajian tersebut dapat di rumuskan hipotesis pertama seperti dibawah ini.

H3: Ada pengaruh antara pengungkapan sustainability report dimensi sosial (SO) dengan kinerja keuangan.

\section{METODE PENELITIAN}

Populasi dari penelitian ini adalah seluruh perusahaan yang telah melaporkan keberlanjutan organisasi dari aspek, sosial (SO). ekonomi (EO), dan lingkungan (EN). Sampel penelitian adalah perusahaan manufaktur, tambang dan jasa, karena ketiga sektor industry tersebut yang memenuhi kriteria menyampaikan sustainability report secara konsisten selama periode 2009-2011. Variabel penelitian adalah skor pengungkapan sustainability report (SR) setiap dimensi (EC, EN, SO) sebagai variabel independen dan kinerja organisasi sebagai variabel dependen.

Untuk menguji hipotesis yang telah disebutkan sebelumnya, hubungan variabel-variabel yang akan diteliti dinyatakan dalam model hipotesis di atas, digunakan analisis varian (ANOVA) satu arah (one way), korelasi, dan regresi linear berganda. Uji ANOVA dan korelasi menggunakan bantuan rogram paket SPSS versi 13, sedangkan uji regresi dilakukan menggunakan pendekatan Structural Equation Modeling (SEM).

Seperti yang sudah dibahas sebelumnya, kinerja keuangan organisasi perusahaan dalam penelitian ini menggunakan konsep dari Ross et al. (2003), yang terbagai dalam lima kelompok rasio keuangan, yaitu dimensi manajemen aset, profitabilitas, leverage, likuiditas dan pasar. Nilai dari variabel dependen ini akan didapatkan dari ratarata setiap rasio keuangan perusahaan yang dijadikan sampel dalam sustainability report. Variabel independen dalam penelitian ini adalah pengungkapan sustainability report. Pengungkapan sustainability report didefinisikan sebagai data yang diungkapkan perusahaan berkaitan dengan aktivitas sosial yang dilakukan perusahaan meliputi tema sebagai berikut: aspek EkonomiEconomics (EC), Lingkungan-Environment (EN) dan Social. Dimana aspek sosial terdiri dari empat sub-dimensi yaitu: Tenaga Kerja-Labor (LA), Hak Asasi Manusia-Human Rights (HR), MasyarakatSociety (SO), dan Tanggung Jawab Produk-Product Responsibility (PR) yang sesuai dengan standar GRI-G3.1 (2011). Variabel ini diukur dengan menggunakan index skor atas nilai kinera sustanaibility report setiap dimensi. Perhitungan dilakukan dengan memberikan skor 1 jika satu item diungkapkan, dan 0 jika tidak diungkapkan dalam laporan yang ada. Setelah dilakukan pemberian skor pada seluruh item, skor tersebut kemudian dijumlahkan untuk memperoleh keseluruhan skor untuk setiap dimensi. Formula untuk perhitungan indeks skor setiap dimensi adalah sebagai berikut:

$$
\text { Index }=\frac{n}{k}
$$

dimana:

Index $=$ Indeks skor setiap dimensi

$\mathrm{n} \quad=$ Jumlah item yang diungkapkan setiap dimensi

$\mathrm{k}=$ Jumlah item yang diharapkan setiap dimensi

Data penelitian yang akan digunakan adalah data yang menggunakan skala rasio dan nominal dimana mencerminkan nilai kuantitatif aktual dari variabel yang diukur dan telah disebutkan di atas. Nilai atas indeks skor yang diperoleh dari 27 sustainability report perusahaan yang secara konsisten dilaporkan selaam periode 2009-2011. Sedangkan nilai untuk variabel kinerja perusahaan diperoleh dari 27 laporan keuangan perusahaan dari 2010-2012. Secara total sampel atas penelitian sebanyak 54 pengamatan. 


\section{HASIL PENELITIAN DAN PEMBAHASAN}

\section{Deskripsi Variabel Penelitian}

Analisis deskripsi variabel penelitian didasarkan pada variabel independen maupun variabel dependen. Untuk variabel independen adalah pengungkapan sustainability reportyang sesuai dengan standar GRI-G3 (2011). Variabel ini diukur melalui indeks skor setiap dimensi, yaitu dimensi Economic (EC), Enviromental (EN), Human Rights (HR), Labor Practices (LA) \& Decent Work, Society (SO), dan Product Responsibility (PR). Sedangkan yang termasuk dalam variabel dependen adalah kinerja keuangan yang dibagi menjadi lima kelompok rasio sesuai konsep dari Ross et al. (2003), yaitu dimensi manajemen aset, profitabilitas, leverage, likuiditas dan pasar.

\section{Variabel Pengungkapan Sustainability Report}

Berikut merupakan hasil pengolahan deskripsi variabel Ekonomi (EC) atas Sustainability report. Dari hasil yang terlihat, mean atas EC3 paling besar diikuti oleh EC2 dan terakhir EC1. EC1 merupakan Perolehan dan distribusi nilai ekonomi langsung, meliputi pendapatan, biaya operasi, imbal jasa karyawan, donasi, dan investasi komunitas lainnya, laba ditahan, dan pembayaran kepada penyandang dana serta pemerintah. EC2 adalah Implikasi finansial dan risiko lainnya akibat perubahan iklim serta peluangnya bagi aktivitas organisasi dan EC3 yang merupakan pemberian manfaat ekonomi kepada para karyawan. Hal ini dapat diartikan, berdasarkan data sampel yang ada bahwa komponen yang paling lengkap atas data dan informasi atas sustainability report dari varibel $\mathrm{EC}$ adalah komponen EC3. Manfaat ekonomi dapat diartikan seperti program pensiun kepada para karyawan yang ada. Hal ini bertujuan agar tercipta kondisi lingkungan kerja yang lebih stabil dan keberlanjutan. Seperti yang diungkap oleh Robert Kaplan (2004) sebagai pengembang konsep Balance Scorecard, bahwa kinerja ekonomi itu diawali dengan kepuasan dan loyalitas karyawan. Sebagai kesimpulan, dalam dimensi ekonomi (EC), mayoritas organisasi sudah menyadari bahwa pengungkapan atas kontribusi ekonomi kepada karyawan merupakan pengungkapan informasi yang sangat penting bagi para pemangku kepentingan yang ada.

Tabel 2 merupakan hasil pengolahan deskripsi variabel Envoronment (EN) atas sustainability report. Dari hasil yang terlihat bahwa mean tiga tertinggi adalah EN3, EN2 dan EN5.Hal ini dapat diartikan bahwa komponen yang paling lengkap atas data dan informasi pelaporan dari varibel EN adalah komponen EN3 diikuti oleh EN2 dan EN5. EN5 adalah energi yang dapat dihemat terkait dengan program efisiensi dan pembaharuan yang dilakukan oleh organisasi dan EN2 merupakan total bahan baku yang berasal dari daur ulang. Terakhir EN3 adalah total energi utama yang dikonsumsi langsung oleh organisasi. Semakin besar energy utama yang dikonsumsi maka semakin sedikit penggunaan energi terbarukan. Energi utama seperti layaknya penggunaan sumber energy dari minyak bumi yang merupakan penyebab utama perubahan iklim yang berasal dari emisi karbon.Sebagai kesimpulan dapat dilihat bahwa organisasi bisnis menganggap indikator ini sebagai hal yang paling penting untuk diungkapkan kepada para pemangku kepentingan. Kesadaran organisasi bisnis untuk menghasilkan kinerja yang keberlanjutan sudah baik dengan melihat peran penting dari energi terbarukan melalui pengurangan energy utama dalam menjalankan operasi bisnis.

Tabel 2. Mean dan Standar Deviasi (SD) Pengungkapan Pelaporan Ekonomi (EC)

\begin{tabular}{llccc}
\hline Perusahaan & Statistik & EC 1 & EC 2 & EC 3 \\
\hline PT Adaro Energy & Mean & 0,75 & 1,00 & 1,00 \\
& SD & 0,43 & - & - \\
\hline PT Aneka Tambang & Mean & 1,00 & 1,00 & 1,00 \\
& SD & - & - & - \\
\hline PT Astra International & Mean & 0,58 & 0,67 & 0,83 \\
& SD & 0,29 & - & 0,29 \\
\hline PT Holcim Indonesia & Mean & 0,75 & 1,00 & 1,00 \\
& SD & - & - & - \\
\hline PT Perusahaan Gas & Mean & 0,83 & 0,67 & 1,00 \\
Negara & SD & 0,14 & 0,34 & - \\
\hline PT Petrosea & Mean & 1,00 & 1,00 & 1,00 \\
& SD & - & - & - \\
\hline PT Semen Gresik & Mean & 1,00 & 1,00 & 1,00 \\
& SD & - & - & - \\
\hline PT Tambang Batubara & Mean & 0,83 & 0,78 & 1,00 \\
Bukit Asam & SD & 0,29 & 0,39 & - \\
\hline PT Telekomunikasi & Mean & 1,00 & 1,00 & 1,00 \\
Indonesia & & - & - & - \\
\hline Total & Mean & 0,86 & 0,90 & 0,98 \\
& SD & 0,22 & 0,20 & 0,10 \\
\hline
\end{tabular}

Variabel ketiga atas Sustainability report adalah Sosial (SO) seperti yang dilampirkan dibawah ini. Dari hasil yang terlihat bahwa mean dua tertinggi adalah SO1 dan SO4. Hal ini dapat diartikan bahwa komponen yang paling lengkap atas data dan informasi pelaporan dari varibel SO adalah komponen SO1 dan SO4. SO4 terkait dengan tindakan yang diambil dalam menanggapi kejadian korupsi, sedangkan SO1 merupakan persentase operasional kegiatan yang melibatkan para komunitas lokal. Indikator ini menekankan pada usaha yang dilakukan oleh organisasi dalam melibatkan dan mengevaluasi dampak operasi 
Tabel 3. Mean dan Standar Deviasi (SD) Pengungkapan Pelaporan Lingkungan (EN)

\begin{tabular}{llccccccccc}
\hline Perusahaan & Statistik & EN1 & EN2 & EN3 & EN4 & EN5 & EN6 & EN7 & EN8 & EN9 \\
\hline PT Adaro Energy & Mean & 0,67 & 0,80 & 0,89 & 0,93 & 0,87 & 0,83 & 0,67 & 1,00 & 1,00 \\
& SD & 0,58 & 0,35 & 0,19 & 0,12 & 0,23 & 0,29 & 0,58 & - & - \\
\hline PT Aneka Tambang & Mean & 1,00 & 1,00 & 1,00 & 1,00 & 1,00 & 1,00 & 1,00 & 1,00 & 1,00 \\
& SD & - & - & - & - & - & - & - & - & - \\
\hline PT Astra International & Mean & 0,83 & 1,00 & 0,78 & 0,67 & 0,50 & 0,33 & - & 0,33 & - \\
& SD & 0,29 & - & 0,19 & 0,58 & 0,44 & 0,29 & - & 0,58 & - \\
\hline PT Holcim Indonesia & Mean & 0,50 & 0,60 & 1,00 & 0,40 & 0,60 & 0,50 & 1,00 & - & - \\
& SD & - & - & - & - & - & - & - & - & - \\
\hline PT Perusahaan Gas Negara & Mean & 0,33 & 0,60 & 0,67 & 0,40 & 0,67 & 0,50 & 0,67 & 0,67 & 0,67 \\
& SD & 0,58 & 0,20 & 0,58 & 0,35 & 0,49 & 0,50 & 0,58 & 0,58 & 0,58 \\
\hline PT Petrosea & Mean & 1,00 & 1,00 & 1,00 & 1,00 & 1,00 & 1,00 & 1,00 & 1,00 & 1,00 \\
& SD & - & - & - & - & - & - & - & - & - \\
\hline PT Semen Gresik & Mean & 1,00 & 1,00 & 1,00 & 1,00 & 1,00 & 1,00 & 1,00 & 1,00 & 1,00 \\
& SD & - & - & - & - & - & - & - & - & - \\
\hline PT Tambang Batubara Bukit Asam & Mean & 1,00 & 0,80 & 0,67 & 0,93 & 0,77 & 1,00 & 0,67 & 0,67 & 1,00 \\
& SD & - & 0,35 & 0,58 & 0,12 & 0,40 & - & 0,58 & 0,58 & - \\
\hline PT Telekomunikasi Indonesia & Mean & 0,67 & 0,87 & 0,78 & 0,73 & 0,77 & 0,67 & 1,00 & 0,67 & 1,00 \\
& & 0,58 & 0,23 & 0,39 & 0,46 & 0,40 & 0,58 & - & 0,58 & - \\
\hline Total & Mean & 0,78 & 0,85 & 0,86 & 0,79 & 0,80 & 0,76 & 0,78 & 0,70 & 0,74 \\
& SD & 0,38 & 0,23 & 0,30 & 0,33 & 0,31 & 0,35 & 0,42 & 0,47 & 0,45 \\
\hline
\end{tabular}

organisasi terhadap komunitas lokal. Usaha tersebut dimulai dari melakukan diskusi dengan para komunitas lokal terkait dengan cara melakukan operasi yang memiliki dampak negatif paling kecil dan memberikan solusi atas dampak yang terjadi atas komunitas lokal tersebut. Sebagai kesimpulan, organisasi bisnis sudah menyadari bahwa penting untuk melibatkan komunitas lokal dalam operasi bisnis mereka termasuk mengevaluasi dampak keberadaan organisasi bisnis tersebut didalam komunitas yang ada.

Tabel 4. Mean dan Standar Deviasi (SD) Pengungkapan Pelaporan Sosial (SO)

\begin{tabular}{|c|c|c|c|c|c|}
\hline Perusahaan & Statistik & SO 1 & $\mathrm{SO} 2$ & $\mathrm{SO} 3$ & SO 4 \\
\hline \multirow[t]{2}{*}{ PT Adaro Energy } & Mean & 0,90 & 0,56 & 0,71 & 0,67 \\
\hline & $\mathrm{SD}$ & 0,17 & 0,51 & 0,50 & 0,58 \\
\hline \multicolumn{2}{|c|}{ PT Aneka Tambang Mean } & 1,00 & 1,00 & 1,00 & 1,00 \\
\hline & $\mathrm{SD}$ & - & - & - & - \\
\hline PT Astra & Mean & 0,62 & 0,48 & 0,46 & 0,37 \\
\hline International & SD & 0,48 & 0,32 & 0,31 & 0,34 \\
\hline PT Holcim & Mean & 0,90 & 0,82 & 0,79 & 1,00 \\
\hline Indonesia & $\mathrm{SD}$ & 0,17 & 0,06 & 0,08 & - \\
\hline \multicolumn{2}{|c|}{ PT Perusahaan Gas Mean } & 0,93 & 0,71 & 0,58 & 0,67 \\
\hline Negara & $\mathrm{SD}$ & 0,12 & 0,13 & 0,14 & 0,23 \\
\hline \multirow[t]{2}{*}{ PT Petrosea } & Mean & 1,00 & 1,00 & 1,00 & 1,00 \\
\hline & SD & - & - & - & - \\
\hline \multirow[t]{2}{*}{ PT Semen Gresik } & Mean & 0,95 & 0,85 & 0,84 & 1,00 \\
\hline & SD & 0,04 & 0,17 & 0,19 & - \\
\hline \multirow{2}{*}{\multicolumn{6}{|c|}{$\begin{array}{l}\text { PT Tambang Mea } \\
\text { Batubara Bukit }\end{array}$}} \\
\hline & & & & & \\
\hline Asam & $\mathrm{SD}$ & 0,12 & 0,51 & 0,21 & 0,39 \\
\hline \multirow{2}{*}{$\begin{array}{l}\text { PT Telekomunikasi } \\
\text { Indonesia }\end{array}$} & Mean & 1,00 & 1,00 & 0,96 & 0,96 \\
\hline & & - & - & 0,07 & 0,06 \\
\hline \multirow[t]{2}{*}{ Total } & Mean & 0,92 & 0,79 & 0,80 & 0,83 \\
\hline & SD & 0,19 & 0,29 & 0,26 & 0,31 \\
\hline
\end{tabular}

\section{Deskripsi Variabel Kinerja Keuangan}

Dari data deskripsi dimensi manajemen asset, terlihat bahwa mean tertinggi adalah Aset 1 (Inventory Turnover) dan kedua adalah Aset 2 (Receivables Turnover ratios). PT Perusahaan Gas Negara sebagai organisasi yang memiliki Mean tertinggi atas inventory turnover sedangkan untuk receivable turnover berasal dari PT Telekomunikasi Indonesia.

Tabel 5. Mean dan Standar Deviasi (SD) Aset Perusahaan

\begin{tabular}{|c|c|c|c|c|c|c|}
\hline Perusahaan & $\begin{array}{c}\text { Statis- } \\
\text { tik }\end{array}$ & Ase & $\mathbf{A}_{\mathrm{c}}$ & Aset & Aset & Aset5 \\
\hline T Adaro & Mean & & 876 & & 256 & \\
\hline & $\mathrm{SD}$ & & & & & \\
\hline$\overline{\mathrm{PT} \mathrm{Ar}}$ & Mean & & & & 9 & \\
\hline & SD & & & & & \\
\hline \multirow{2}{*}{$\begin{array}{l}\text { PT Astra Inter } \\
\text { national }\end{array}$} & - Mean & & & & & \\
\hline & SD & & & & & \\
\hline \multirow{2}{*}{$\begin{array}{l}\text { PT Holcim } \\
\text { Indonesia }\end{array}$} & Mea & & & & & \\
\hline & $\mathrm{SD}$ & & & & & \\
\hline \multirow{2}{*}{$\begin{array}{l}\text { PT Perusaha- } \\
\text { an Gas } \\
\text { Negara }\end{array}$} & Mean & 541 & 10 & 1,82 & 1,3 & 0,64 \\
\hline & SD & 106,10 & 0,33 & 0,16 & 0,18 & 0,02 \\
\hline \multirow[t]{2}{*}{ PT Petrosea } & Mean & & & & 1, & \\
\hline & $\mathrm{SD}$ & & & & 0 , & 0,07 \\
\hline \multirow{2}{*}{$\begin{array}{l}\text { PT Semen } \\
\text { Gresik }\end{array}$} & Mean & & & & 1, & 0,83 \\
\hline & $\mathrm{SD}$ & & & & 0, & - \\
\hline \multirow{2}{*}{$\begin{array}{l}\text { PT Tambang } \\
\text { Batubara } \\
\text { Bukit Asam }\end{array}$} & Mean & & 8, & 1,54 & 8,04 & 0,91 \\
\hline & SD & 0,99 & 0,76 & 0,12 & 1,58 & 0,01 \\
\hline \multirow{2}{*}{$\begin{array}{l}\text { PT Teleko- } \\
\text { munikasi } \\
\text { Indonesia }\end{array}$} & Mean & 79,90 & 10,02 & & 0,95 & 0,69 \\
\hline & & 12,09 & 0,69 & 48,66 & 0,05 & \\
\hline \multirow[t]{2}{*}{ Total } & M & & $O, c$ & & 3,14 & 0,85 \\
\hline & SD & 170,29 & 3,19 & 24,59 & 2,36 & 0,28 \\
\hline
\end{tabular}


Dari data deskripsi dimensi Profitabilitas, terlihat bahwa, mean tertinggi adalah ROE (Return on Equity) dan diikuti oleh Profit Margin. Untuk ROE dan Profit Margin tertinggi adalah PT Perusahaan Gas Negara.

Tabel 6. Mean dan Standar Deviasi (SD) Profit Margin, ROA, dan ROE

\begin{tabular}{llllll}
\hline Perusahaan & Statistik & PMargin & ROA & ROE \\
\hline \multirow{2}{*}{ PT Adaro Energy } & Mean & 0,11 & 0,07 & 0,14 \\
& SD & 0,03 & 0,02 & 0,03 \\
\hline \multirow{2}{*}{ PT Aneka Tambang } & Mean & 0,22 & 0,14 & 0,19 \\
& SD & 0,06 & 0,01 & 0,03 \\
\hline \multirow{2}{*}{ PT Astra International } & Mean & 0,22 & 0,22 & 0,27 \\
& SD & 0,02 & 0,03 & 0,02 \\
\hline \multirow{2}{*}{ PT Holcim Indonesia } & Mean & 0,14 & 0,10 & 0,14 \\
& SD & 0,01 & 0,02 & 0,02 \\
\hline \multirow{2}{*}{ PT Perusahaan Gas } & Mean & 0,33 & 0,21 & 0,40 \\
Negara & SD & 0,03 & 0,02 & 0,04 \\
\hline \multirow{2}{*}{ PT Petrosea } & Mean & 0,16 & 0,16 & 0,31 \\
& SD & 0,04 & 0,06 & 0,05 \\
\hline \multirow{2}{*}{ PT Semen Gresik } & Mean & 0,24 & 0,21 & 0,28 \\
\multirow{2}{*}{ PT Tambang Batubara } & SD & 0,02 & 0,03 & 0,02 \\
Bukit Asam & SD & 0,21 & 0,23 & 0,34 \\
PT Telekomunikasi & Mean & 0,03 & 0,01 & 0,04 \\
Indonesia & & 0,23 & 0,15 & 0,27 \\
\multirow{2}{*}{ Total } & Mean & 0,21 & 0,01 & 0,02 \\
\hline
\end{tabular}

Dari data deskripsi dimensi Leverage, terlihat bahwa mean tertinggi adalah Leverage 3 (Cash Coverage) dan Leverage 2 (Time Interest Earned). Organisasi bisnis yang mencetak nilai tertinggi atas kedua rasio keuangan diatas adalah PT Tambang Batubara Bukit Asam.

Tabel 7. Mean dan Standar Deviasi (SD) Leverage Perusahaan

\begin{tabular}{llcrrr}
\hline Perusahaan & Statistik & $\begin{array}{r}\text { Leve- } \\
\text { rage1 }\end{array}$ & $\begin{array}{r}\text { Leve- } \\
\text { rage2 }\end{array}$ & $\begin{array}{r}\text { Leve- } \\
\text { rage3 }\end{array}$ \\
\hline PT Adaro Energy & Mean & 5,02 & 7,55 & 9,72 \\
& SD & 6,51 & 1,69 & 2,37 \\
\hline PT Aneka Tambang & Mean & 0,41 & 82,68 & 125,83 \\
& SD & 0,14 & 76,07 & 101,28 \\
\hline PT Astra International & Mean & 1,06 & 25,00 & 32,67 \\
& SD & 0,05 & 5,48 & 7,20 \\
\hline PT Holcim Indonesia & Mean & 0,48 & 7,56 & 10,07 \\
& SD & 0,05 & 4,11 & 5,16 \\
\hline PT Perusahaan Gas & Mean & 0,87 & 34,67 & 40,97 \\
Negara & SD & 0,25 & 11,57 & 13,44 \\
\hline PT Petrosea & Mean & 1,35 & 9,23 & 15,65 \\
& SD & 0,50 & 3,42 & 5,81 \\
\hline PT Semen Gresik & Mean & 0,36 & 136,35 & 150,56 \\
& SD & 0,09 & 67,01 & 73,65 \\
\hline PT Tambang Batubara & Mean & 0,42 & 721,50 & 810,78 \\
Bukit Asam & SD & 0,08 & 585,15 & 656,25 \\
\hline PT Telekomunikasi & Mean & 0,91 & 12,54 & 20,39 \\
Indonesia & & 0,07 & 0,66 & 1,52 \\
\hline Total & Mean & 1,21 & 115,23 & 135,18 \\
& SD & 2,30 & 276,78 & 309,98 \\
\hline
\end{tabular}

Tabel 8 merupakan data deskripsi dimensi Likuiditas dan Pasar. Untuk dimensi Likuiditas terlihat bahwa mean tertinggi adalah Liquid 1 (current ratio) dan Pasar 1 (price earning ratio). Organisasi yang mencetak current ratio tertinggi adalah PT Tambang Batubara Bukit Asam, sedangkan nilai price earning ratio tertinggi adalah PT Adaro Energy.

Tabel 8. Deskripsi Data Dimensi Likuiditas dan Pasar

\begin{tabular}{|c|c|c|c|c|c|c|}
\hline \multirow{2}{*}{ Perusahaan } & \multirow{2}{*}{ Statistil } & \multicolumn{2}{|c|}{ Liquid Liquid } & \multicolumn{3}{|c|}{ Liquid Pasar Pasar } \\
\hline & & 1 & 2 & 3 & 1 & 2 \\
\hline \multirow{2}{*}{$\begin{array}{l}\text { PT Adaro } \\
\text { Energy }\end{array}$} & Mean & 1,74 & 1,66 & 0,78 & 20,41 & 9,77 \\
\hline & SD & 0,06 & 0,06 & 0,14 & 17,93 & 11,69 \\
\hline \multirow{2}{*}{$\begin{array}{l}\text { PT Aneka } \\
\text { Tambang }\end{array}$} & Mea & 5,91 & 4,84 & 3,57 & 8,65 & 1,61 \\
\hline & & 11 & 3,33 & 2,62 & 4,92 & 0,76 \\
\hline \multirow{2}{*}{$\begin{array}{l}\text { PT Astra Inter } \\
\text { national }\end{array}$} & & 1,34 & 1,07 & 0,22 & 16,17 & 0,39 \\
\hline & $\mathrm{SD}$ & 0,07 & 0,09 & 0,04 & 0,59 & 0,06 \\
\hline \multirow{2}{*}{$\begin{array}{l}\text { PT Holcim } \\
\text { Indonesia }\end{array}$} & &, 51 & 1,13 & 0,61 & 17,65 & 2,46 \\
\hline & & 13 & 0,17 & 0,22 & 2,78 & 0,22 \\
\hline \multirow{2}{*}{$\begin{array}{l}\text { PT Perusaha- } \\
\text { an Gas } \\
\text { Negara } \\
\end{array}$} & Mean & 4,38 & 4,37 & 3,41 & 14,02 & 5,70 \\
\hline & $\mathrm{SD}$ & 1,05 & 1,04 & 0,72 & 2,82 & 1,77 \\
\hline \multirow{2}{*}{ PT Petrosea } & Mea & 0,98 & 0,90 & 0,20 & 3,52 & 0,18 \\
\hline & $\mathrm{SD}$ & 0,05 & 0,05 & 0,09 & 3,17 & 0,10 \\
\hline \multirow{2}{*}{$\begin{array}{l}\text { PT Semen } \\
\text { Gresik }\end{array}$} & Mer & 1,55 & $(0,48)$ & 1,09 & 17,37 & 4,83 \\
\hline & $\mathrm{SD}$ & 1,19 & 2,49 & 0,42 & 1,99 & 0,30 \\
\hline \multirow{2}{*}{$\begin{array}{l}\text { PT Tambang } \\
\text { Batubara } \\
\text { Bukit Asam } \\
\end{array}$} & Mean & 5,11 & 4,84 & 3,76 & 17,08 & 5,76 \\
\hline & SD & 0,60 & 0,51 & 0,56 & 8,01 & 2,25 \\
\hline \multirow{2}{*}{$\begin{array}{l}\text { PT Telekomu- } \\
\text { nikasi } \\
\text { Indonesia }\end{array}$} & Mean & 1,01 & 0,98 & 0,47 & 9,61 & 1,85 \\
\hline & SD & 0,13 & 0,14 & 0,06 & 5,99 & 0,99 \\
\hline \multirow{2}{*}{ Total } & & 2,61 & 2,14 & 1,57 & 13,83 & 3,62 \\
\hline & & 2,24 & 2,26 & 1,67 & 8,00 & 4,51 \\
\hline
\end{tabular}

\section{Uji Beda Pengungkapan Sustainability Report}

Setelah melakukan analisa deskripsi, selanjutnya analisa dilakukan dengan melakukan uji beda atas dimensi yang ada dalam sustainability report (EC, EN, SO). Hal ini dilakukan untuk melihat apakah ada perbedaan indeks pelaporan tiga dimensi (EC, EN, SO) dari masing-masing perusahaan. Hasil pengujian tersebut kemudian dapat memberi kesimpulan apakah ada kaitan antara hasil pelaporan dengan kinerja keuangan yang dimiliki. Pertama, dilakukan atas dimensi ekonomi (EC). Berdasarkan uji beda yang dilakukan dapat disimpulkan bahwa terdapat perbedaan dimensi ekonomi (EC) atas sustainability report yang ada dengan tingkat signifkan $10 \%$ (sig = 0.08 ), sehingga perlu dilihat beberapa perusahaan yang memiliki perbedaan dan yang tidak memiliki perbedaan atas kinerja ekonomi dalam sustainability report yang ada. Hal ini dapat dilihat lebih lanjut dalam Tabel 9. 
Tabel 9. Uji beda dimensi ekonomi (EC)

\begin{tabular}{|c|c|c|c|c|}
\hline $\begin{array}{l}\text { (I) Perusaha- } \\
\text { an Sampel }\end{array}$ & $\begin{array}{l}\text { (J) Perusahaan } \\
\text { Sampel }\end{array}$ & $\begin{array}{c}\text { Mean } \\
\text { Difference } \\
\text { (I-J) }\end{array}$ & $\begin{array}{l}\text { Std. } \\
\text { Error }\end{array}$ & Sig. \\
\hline \multirow{14}{*}{$\begin{array}{l}\text { PT Astra } \\
\text { International }\end{array}$} & PT Adaro Energy & $(0,221)$ & 0,099 & 0,039 \\
\hline & PT Aneka & & & \\
\hline & Tambang & $(0,304)$ & 0,099 & 0,007 \\
\hline & PT Holcim & & & \\
\hline & Indonesia & $(0,221)$ & 0,099 & 0,039 \\
\hline & PT Perusahaan & & & \\
\hline & Gas Negara & $(0,138)$ & 0,099 & 0,181 \\
\hline & PT Petrosea & $(0,304)$ & 0,099 & 0,007 \\
\hline & PT Semen Gresik & $(0,304)$ & 0,099 & 0,007 \\
\hline & PT Tambang & & & \\
\hline & Batubara & & & \\
\hline & Bukit & $(0,174)$ & 0,099 & 0,095 \\
\hline & $\begin{array}{l}\text { PT Telekomu- } \\
\text { nikasi Indone- }\end{array}$ & & & \\
\hline & sia & $(0,304)$ & 0,099 & 0,007 \\
\hline
\end{tabular}

Berdasarkan Tabel 9, terlihat bahwa ada perbedaan siginifkan indeks pengungkapan ekonomi antara PT Astra International dengan perusahaan lainnya, kecuali PT Perusahaan Gas Negara (PGN). Perbedaan siginifikan tersebut menunjukkan kinerja pengungkapan sustainability report PT Astra Internasional dalam hal dimensi ekonomi (EC) lebih rendah dibandingkan lainnya, dimana hal ini terlihat dari "mean difference" yang negatif. Terlihat bahwa pengungkapan dimensi ekonomi ini cukup dipengaruhi oleh jenis organisasi itu sendiri. PT Astra merupakan organisasi produsen otomotif, sedangkan PGN merupakan distributor gas. Terlihat bahwa kedua organisasi ini bukan merupakan organisasi yang langsung berhubungan dengan pengolahan atau produksi sumber daya alam. Berbeda halnya dengan PT Adaro Energy, PT Aneka Tambang, PT Petrosea, PT Tambang Batubara, PT Semen Gresik dan PT Holcim.

Kedua, dilakukan atas dimensi lingkungan (EN). Sama halnya dengan dimensi ekonomi, dalam dimensi lingkungan (EN) juga terdapat perbedaan indeks "EN" antar perusahaan dengan tingkat signifkan $10 \%$ ( $\mathrm{sig}=0.07$ ). Perusahaan yang memiliki perbedaan signifikan dengan Astra terdapat empat, yakni PT Adaro Energy, PT Aneka Tambang, PT Petrosea dan PT Semen Gresik. Sedikit berbeda dengan dimensi ekonomi (EC), kinerja perusahaan atas dimensi lingkungan (EN) yang sekelompok dengan PT Astra Internasional bukan hanya PT Perusahaan Gas Negara namun juga PT Holcim Indonesia, PT Tambang Batubara Bukit dan PT Telekomunikasi Indonesia. Hal ini menunjukkan bahwa bagi organisasi lebih sulit untuk memenuhi kriteria dimensi lingkungan (EN) dibandingkan ekonomi (EC). Hal ini terlihat dari tiga organisasi seperti PT Holcim Indonesia, PT Tambang Batubara Bukit dan PT Telekomunikasi Indonesia yang masuk dalam kelompok astra untuk dimensi lingkungan (EN) dimana sebelumnya berbeda dalam dimensi ekonomi (EC).

Tabel 10. Uji beda dimensi lingkungan (EN)

\begin{tabular}{|c|c|c|c|c|}
\hline $\begin{array}{l}\text { (I) Perusaha- } \\
\text { an Sampel }\end{array}$ & $\begin{array}{l}\text { (J) Perusahaan } \\
\text { Sampel }\end{array}$ & $\begin{array}{c}\text { Mean } \\
\text { Difference } \\
\text { (I-J) }\end{array}$ & $\begin{array}{l}\text { Std. } \\
\text { Error }\end{array}$ & Sig. \\
\hline \multirow{16}{*}{$\begin{array}{l}\text { PT Astra } \\
\text { International }\end{array}$} & PT Adaro & \multirow{3}{*}{$(0,357)$} & \multirow{3}{*}{0,196} & \multirow{3}{*}{0,086} \\
\hline & Energy & & & \\
\hline & PT Aneka & & & \\
\hline & Tambang & \multirow[t]{2}{*}{$(0,506)$} & \multirow[t]{2}{*}{0,196} & \multirow[t]{2}{*}{0,019} \\
\hline & PT Holcim & & & \\
\hline & Indonesia & \multirow[t]{2}{*}{$(0,017)$} & \multirow[t]{2}{*}{0,196} & \multirow[t]{2}{*}{0,932} \\
\hline & PT Perusahaan & & & \\
\hline & Gas Negara & $(0,080)$ & 0,196 & 0,688 \\
\hline & PT Petrosea & $(0,506)$ & 0,196 & 0,019 \\
\hline & PT Semen & & & \\
\hline & Gresik & $(0,506)$ & 0,196 & 0,019 \\
\hline & PT Tambang & & & \\
\hline & Batubara & & & \\
\hline & Bukit & $(0,339)$ & 0,196 & 0,101 \\
\hline & $\begin{array}{l}\text { PT Telekomu- } \\
\text { nikasi }\end{array}$ & & & \\
\hline & Indonesia & $(0,300)$ & 0,196 & 0,144 \\
\hline
\end{tabular}

Ketiga dan terakhir dalam konteks dimensi sosial (SO), terlihat tidak ada perbedaan signifikan antar perusahaan. Oleh karena itu tidak terdapat perbedaan indeks "SO" untuk masing-masing perusahaan, berbeda pada kasus Ekonomi (EC) dan Lingkungan (EN).

\section{Uji Beda Kinerja Keuangan (Laporan Keuangan)}

Setelah melakukan analisa uji beda atas variabel pengungkapan sustainability report, maka dilanjutkan dengan analisa atas variabel kinerja keuangan. Dalam penelitian ini, seperti yang sudah dibahas sebelumnya, dimensi yang digunakan dalam pengukuran kinerja keuangan adalah rasio Manajemen Aset, Profitabilitas, Leverage, Likuiditas dan Pasar. Pertama, dari dimensi Manajemen Aset, terlihat bahwa terdapat perbedaan kepemilikan aset secara signifikan (uji 5\%). Terdapat perbedaan Manajemen Aset antara PT Gas Negara dengan perusahaan lainnya yang diukur dengan menggunakan empat ukuran, yaitu: Inventory Turnover, Receivables Turnover, Net Working Capital Turnover, Fixed Asset Turnover dan Total Asset Turnover. 
Tabel 11. Uji beda dimensi manajemen aset

\begin{tabular}{lrrrrr}
\hline \multicolumn{1}{c}{$\begin{array}{c}\text { Sumber } \\
\text { Keragaman }\end{array}$} & \multicolumn{1}{c}{$\begin{array}{c}\text { Sum of } \\
\text { Squares }\end{array}$} & df & $\begin{array}{c}\text { Mean } \\
\text { Square }\end{array}$ & F & Sig. \\
\hline Between Groups & $28.935,75$ & 8,00 & $3.616,97$ & 45,07 & 0,00 \\
Within Groups & $1.444,51$ & 18,00 & 80,25 & & \\
\hline Total & $30.380,26$ & 26,00 & & & \\
\hline
\end{tabular}

Dari data Tabel 12 terlihat bahwa untuk dimensi Manajemen Aset, terlihat bahwa terdapat dua kelompok perusahaan, yakni kelompok 1 dan kelompok 2. Kelompok 2, yaitu memiliki rasio Manajement Aset yang jauh lebih baik secara siginifikan (uji 5\%) dibandingkan 8 perusahaan lainnya yang terletak pada kelompok 1. Padahal dalam kinerja pengungkapan sustainability report untuk dimensi ekonomi (EC) dan lingkungan (EN), PT Perusahaan Gas Negara secara signifikan satu kelompok dengan Astra yang artinya siginifikan lebih rendah dibandingkan organisasi lainnya.

Tabel 12. Pengelompokan berdasarkan manajemen aset

\begin{tabular}{|c|c|c|c|}
\hline \multirow{2}{*}{ Perusahaan Sampel } & \multirow{2}{*}{$\mathrm{N}$} & \multicolumn{2}{|c|}{$\begin{array}{l}\text { Subset for alpha }= \\
.05\end{array}$} \\
\hline & & 1 & 2 \\
\hline PT Aneka Tambang & 3 & 3,36 & \\
\hline PT Semen Gresik & 3 & 3,86 & \\
\hline PT Holcim Indonesia & 3 & 3,89 & \\
\hline PT Tambang Batubara Bukit & 3 & 5,51 & \\
\hline PT Astra International & 3 & 7,85 & \\
\hline PT Petrosea & 3 & 9,13 & \\
\hline PT Telekomunikasi Indonesia & 3 & 12,92 & \\
\hline PT Adaro Energy & 3 & 13,70 & \\
\hline PT Perusahaan Gas Negara & 3 & & 111,06 \\
\hline Sig. & & 0,88 & 1,00 \\
\hline
\end{tabular}

Kedua, dari sisi dimensi Profitabilitas, terlihat bahwa terdapat perbedaan profitabilitas diantara kelompok perusahaan dengan signifikan $1 \%$ (sig = 0.000), yang diukur dengan menggunakan tiga indikator yaitu: Profit Margin, ROA (Return on Assets), ROE (Return on Equity).

Tabel 13. Uji beda dimensi profitabilitas

\begin{tabular}{lccccc}
\hline \multicolumn{1}{c}{$\begin{array}{c}\text { Sumber } \\
\text { Keragaman }\end{array}$} & $\begin{array}{c}\text { Sum of } \\
\text { Squares }\end{array}$ & df & $\begin{array}{c}\text { Mean } \\
\text { Square }\end{array}$ & F & Sig. \\
\hline Between Groups & 0,10 & 8 & 0,01 & 21,87 & 0,00 \\
Within Groups & 0,01 & 18 & 0,00 & & \\
\hline Total & 0,11 & 26 & & & \\
\hline
\end{tabular}

Dari data Tabel 14 terlihat bahwa untuk dimensi Profitabilitas, terlihat bahwa terdapat lima kelompok perusahaan, yakni kelompok 1-5 yang memiliki profitabilitas yang berbeda. Sama halnya dengan kinerja manajemen aset, dalam hal uji beda kinerja profitabilitas (keuangan), PT Perusahaan Gas Negara (PGN) memiliki kinerja tertinggi yang berbeda secara signifikan dibandingkan dengan organisasi lain. Dimana hal ini bertolak belakang, PGN memiliki kinerja ekonomi (EC) dan lingkungan (EN) masuk kedalam kelompok yang rendah secara signifikan dibaningkan organisasi lainnya.

Tabel 14. Pengelompokan berdasarkan profitabilitas

\begin{tabular}{|c|c|c|c|c|c|c|}
\hline \multirow{2}{*}{ Perusahaan Sampe] } & \multirow{2}{*}{$\mathrm{N}$} & \multicolumn{5}{|c|}{ Subset for alpha $=.05$} \\
\hline & & 1 & 2 & 3 & 4 & 5 \\
\hline PT Adaro Energy & 3 & 0,108 & & & & \\
\hline PT Holcim & & & & & & \\
\hline Indonesia & 3 & 0,127 & 0,127 & & & \\
\hline P'T Aneka Tambang & 3 & & 0,186 & 0,186 & & \\
\hline PT Petrosea & 3 & & & 0,213 & 0,213 & \\
\hline PT Telekomunikasi & & & & & & \\
\hline Indonesia & 3 & & & 0,216 & 0,216 & \\
\hline $\begin{array}{l}\text { PT Astra Inter- } \\
\text { national }\end{array}$ & 3 & & & 0,237 & 0,237 & \\
\hline $\begin{array}{l}\text { PT Semen Gresik } \\
\text { PT Tambang }\end{array}$ & 3 & & & 0,242 & 0,242 & \\
\hline Batubara Bukit & 3 & & & & 0,262 & 0,262 \\
\hline PT Perusahaan Gas & & & & & & \\
\hline Negara & 3 & & & & & 0,316 \\
\hline Sig. & & 0,985 & 0,128 & 0,156 & 0,297 & 0,208 \\
\hline
\end{tabular}

Ketiga, dari dimensi Leverage, terlihat bahwa terdapat perbedaan leverage dengan signifikan $5 \%$ (sig $=0.01$ ), yang diukur dengan menggunakan tiga indikator yaitu: Debt Equity Ratio, Time Interedt Earned Ratio dan Cash Coverage Ratio.

Tabel 15. Uji beda dimensi leverage

\begin{tabular}{lccccc}
\hline $\begin{array}{c}\text { Sumber } \\
\text { Keragaman }\end{array}$ & $\begin{array}{c}\text { Sum of } \\
\text { Squares }\end{array}$ & df & $\begin{array}{c}\text { Mean } \\
\text { Square }\end{array}$ & F & Sig. \\
\hline Between Groups & $639.157,15$ & 8,00 & $79.894,64$ & 4,06 & 0,01 \\
Within Groups & $354.071,95$ & 18,00 & $19.670,66$ & & \\
Total & $993.229,09$ & 26,00 & & & \\
\hline
\end{tabular}

Dari data Tabel 16 terlihat bahwa untuk dimensi Leverage, terlihat bahwa terdapat dua kelompok perusahaan, yakni kelompok 1-2 yang memiliki leverage yang berbeda. Terlihat PT Tambang Batubara Bukit memiliki perbedaan leverage dengan kelompok perusahaan lainnya. Kinerja Leverage terbaik dicetak oleh PT Holcim Indonesia, dengan memiliki rasio terendah. Namun sama halnya dengan kondisi PT PGN sebelumnya, dimana dalam hal kinerja sustainability report untuk dimensi lingkungan (EN), PT Holcim masuk kedalam kelompok kinerja "EN" yang signifikan lebih rendah dibandingkan organisasi lainnya.

Keempat, dari dimensi Likuiditas, terlihat bahwa terdapat perbedaan Likuiditas dengan signifikan 1\% (sig = 0.00), yang diukur dengan menggunakan tiga indikator yaitu: Current Ratio, Quick Ratio dan Cash Ratio. 
Tabel 16. Pengelompokan berdasarkan leverage

\begin{tabular}{|c|c|c|c|}
\hline \multirow[t]{2}{*}{ Perusahaan Sampel } & \multirow[t]{2}{*}{$\mathrm{N}$} & \multicolumn{2}{|c|}{$\begin{array}{l}\text { Subset for alpha }= \\
.05\end{array}$} \\
\hline & & 1 & 2 \\
\hline PT Holcim Indonesia & 3 & 6,038 & \\
\hline PT Adaro Energy & 3 & 7,429 & \\
\hline PT Petrosea & 3 & 8,742 & \\
\hline PT Telekomunikasi Indonesia & 3 & 11,281 & \\
\hline PT Astra International & 3 & 19,576 & \\
\hline PT Perusahaan Gas Negara & 3 & 25,503 & \\
\hline PT Aneka Tambang & 3 & 69,640 & \\
\hline PT Semen Gresik & 3 & 95,759 & \\
\hline PT Tambang Batubara Bukit & 3 & & 510,899 \\
\hline Sig. & & 0,996 & 1,000 \\
\hline
\end{tabular}

Tabel 17. Uji beda dimensi likuiditas

\begin{tabular}{lrrccc}
\hline \multicolumn{1}{c}{$\begin{array}{c}\text { Sumber } \\
\text { Keragaman }\end{array}$} & $\begin{array}{r}\text { Sum of } \\
\text { Squares }\end{array}$ & Df & $\begin{array}{c}\text { Mean } \\
\text { Square }\end{array}$ & F & Sig. \\
\hline Between Groups & 76,80 & 8,00 & 9,60 & 6,32 & 0,00 \\
Within Groups & 27,34 & 18,00 & 1,52 & & \\
\hline Total & 104,14 & 26,00 & & & \\
\hline
\end{tabular}

Dari data Tabel 18 terlihat bahwa untuk dimensi Likuiditas, terlihat bahwa terdapat tiga kelompok perusahaan, yakni kelompok 1-3 yang memiliki Likuiditas yang berbeda.Kinerja PT Perusahaan Gas Negara dan PT Tambang Batubara Bukit terletak pada kelompok "3" yang merupakan kelompok yang memiliki nilai likuiditas secara signifikan terbaik.Namun kedua organisasi tersebut dalam hal kinerja sustainability report untuk dimensi lingkungan (EN) masuk kedalam kelompok kinerja "EN" yang signifikan paling rendah dibandingkan organisasi lainnya.

Tabel 18. Pengelompokan berdasarkan likuiditas

\begin{tabular}{lcccc}
\hline \multirow{2}{*}{\multicolumn{1}{c}{ Perusahaan Sampel }} & \multicolumn{4}{c}{ Subset for alpha $=$} \\
\cline { 3 - 5 } & N & \multicolumn{4}{c}{.05} \\
\hline PT Petrosea & 3 & 0,69 & 2,00 & 3,00 \\
PT Semen Gresik & 3 & 0,72 & & \\
PT Telekomunikasi Indonesia & 3 & 0,82 & & \\
PT Astra International & 3 & 0,88 & & \\
PT Holcim Indonesia & 3 & 1,08 & 1,08 & \\
PT Adaro Energy & 3 & 1,39 & 1,39 & 1,39 \\
PT Perusahaan Gas Negara & 3 & 4,05 & 4,05 & 4,05 \\
PT Tambang Batubara Bukit & 3 & & 4,57 & 4,57 \\
PT Aneka Tambang & 3 & & & 4,77 \\
Sig. & & 0,07 & 0,05 & 0,07 \\
\hline
\end{tabular}

Kelima, dari dimensi Pasar, terlihat bahwa terdapat perbedaan rasio Pasar diantara perusahaan dengan signifikan $10 \%$ (sig $=0.08$ ) yang diukur dengan menggunakan dua indikator yaitu: Price Earning Ratio dan Market Book Value. Namun dengan tingkat signifikan 10\%, maka terlihat hanya 2 kelompok perusahaan yaitu kelompok pertama PT Petrosea sendiri yang memi- liki rasio pasar tertinggi. Kelompok perusahaan memiliki rasio pasar yang lebih rendah dibandingkan PT Petrosea seperti PT Adaro Energy, PT Aneka Tambang, PT Astra International, PT Holcim Indonesia, PT Perusahaan Gas Negara, PT Semen Gresik, PT Tambang Batubara Bukit dan PT Telekomunikasi Indonesia.

Tabel 19. Uji beda dimensi pasar

\begin{tabular}{lcrccc}
\hline \multicolumn{1}{c}{$\begin{array}{c}\text { Sumber } \\
\text { Keragaman }\end{array}$} & $\begin{array}{c}\text { Sum of } \\
\text { Squares }\end{array}$ & Df & $\begin{array}{c}\text { Mean } \\
\text { Square }\end{array}$ & F & Sig. \\
\hline Between Groups & 377,74 & 8,00 & 47,22 & 2,16 & 0,08 \\
Within Groups & 392,85 & 18,00 & 21,83 & & \\
\hline Total & 770,59 & 26,00 & & & \\
\hline
\end{tabular}

\section{Uji Regresi}

Setelah melakukan uji beda maka selanjutnya dilakukan uji regresi untuk melihat pengaruh masing-masing variabel independen terhadap variabel dependen. Hasil uji regresi secara keseluruhan disajikan pada Tabel 20.

Tabel 20. Hasil Uji Regresi

\begin{tabular}{cccccc}
\hline \multirow{6}{*}{ Hipotesis } & \multicolumn{2}{c}{ Original Mean of } & Sample & Sub- \\
Estimate samples & $\begin{array}{c}\text { Standard } \\
\text { deviation }\end{array}$ & T-Sta- & \multirow{2}{*}{ tistic } & Sig \\
\hline H1 & $-0,144$ & $-0,155$ & 0,088 & 1,633 & 0,115 \\
H2 & $-0,115$ & $-0,128$ & 0,039 & 2,974 & $0,006^{* *}$ \\
H3 & $-0,404$ & $-0,388$ & 0,074 & 5,436 & $0,000^{* *}$ \\
\hline
\end{tabular}

** Signifikan $1 \%$

Berdasarkan hasil uji regresi menunjukkan bahwa hipotesis pertama (H1) ditolak, sedangkan kedua hipotesis lainnya, masing-masing H2 dan H3 diterima. Hal ini dapat disimpulkan bahwa tidak terdapat pengaruh antara pengungkapan sustainability report dimensi ekonomi (EC) dengan kinerja keuangan, ada pengaruh antara pengungkapan sustainability report dimensi lingkungan (EN) dengan kinerja keuangan, dan ada pengaruh antara pengungkapan sustainability report dimensi sosial (SO) dengan kinerja keuangan. Fungsi yang menggambarkan pengaruh menyatakan variabel sustainability report yang signifikan terhadap kinerja keuangan seperti yang telah dijelaskan di atas dapat dinyatakan sebaagi berikut:

$$
\text { Kinerja Keuangan }=-0,144 \mathrm{EC}-0.404 \mathrm{SO} \text { - }
$$

$$
0,115 \mathrm{EN}
$$

Walaupun hanya satu hipotesis ditolak, namun dapat dilihat bahwa aspek sustainability berpengaruh negatif terhadap kienrja keuangan. Hal ini sebenarnya sudah terindikasi sejak dilakukan uji beda untuk kinerja sustainability 
report dan kinerja keuangan. Sebagai contoh, dalam hal uji beda kinerja profitabilitas (keuangan), PT Perusahaan Gas Negara (PGN) memiliki kinerja tertinggi yang berbeda secara signifikan dibandingkan dengan organisasi lain. Hal ini bertolak belakang, PGN memiliki kinerja ekonomi (EC) dan lingkungan (EN) masuk ke dalam kelompok yang rendah secara signifikan dibandingkan organisasi lainnya. Lebih jauh, hasilhasil pengujian tersebut mengindikasikan bahwa untuk kondisi di Indonesia, untuk memperoleh kinerja keuangan yang bagus masih dapat dilakukan dengan meletakkan aspek sustainability pada prioritas nomer dua atau tiga. Sustainability report masih menjadi hal yang "nice to have", belum sampai pada tahap "great to have" atau tingkatan yang lebih tinggi lagi adalah "mandatory to have". Hal ini sesuai dengan penelitian yang dilakukan oleh Djajadikerta dan Trireksani (2012), yang menyatakan bahwa kesadaran dan pemahaman tentang sustainability report di Indonesia masih sangat kurang.

Selain itu hasil dari pendanaan yang digunakan untuk sustainability activities seharusnya dapat meningkatkan aset perusahaan baik yang berwujud (tangible asset) maupun aset tak berwujud (intangible asset). Tetapi, pelaporan aset tak berwujud dari sisi laporan keuangan (SAK \& IFRS) masih sangat standar, hanya goodwill, paten, hak cipta dan franchise yang diakui sebagai aset tak berwujud dan dilaporkan dalam neraca, sedangkan pengeluaran investasi lainnya yang berpotensi meningkatkan value of the firm di masa mendatang cenderung diperlakukan sebagai pengeluaran beban (expense) periodik dan disajikan dalam laporan laba-rugi (SWA, 2006). Kondisi inilah yang memunculkan pentingnya wacana untuk mengintegrasikan antara laporan keuangan dengan sustainability report yang kemudian disebut sebagai integrated reporting.

\section{KESIMPULAN DAN SARAN}

Berdasarkan pengujian hipotesis, analis dan pembahasan, dapat disimpulkan bahwa dimensi ekonomi (EC) dari sustainability report tidak berpengaruh terhadap kinerja keuangan. Namun demikian kedua hipotesis yang lain menunjukkan bahwa dimensi lingkungan (EN) dan dimensi sosial (SO) dari sustainability report berpengaruh terhadap kinerja keuangan, meskipun pengaruhnya negatif. Hal ini menunjukkan dalam kondisi saat ini di Indonesia, untuk mencapai kinerja keuangan yang baik, masih dapat dilakukan dengan meletakkan aspek sustainability dalam prioritas nomer dua atau tiga. Seperti diungkapkan oleh Djajadikerta dan Trireksani (2012), bahwa kesadaran dan pemahaman tentang sustainability report di Indonesia masih sangat kurang.
Para pemangku kepentingan di Indonesia belum melihat elemen yang dilaporkan dalam sustainability report sebagai bahan pertimbangan dalam mengambil keputusan. Oleh karena itu itu untuk melihat dampak sustainability report terhadap kinerja keuangan pada penelitian mendatang akan lebih baik jika aspek keberlanjutan tidak hanya melibatkan data kuantitatif saja sekunder (sustainability report dan laporan keuangan), namun juga melibatkan data lain, seperti perilaku manajer atau pemilik yang bisa diperoleh melalui wawancara atau survei.

\section{DAFTAR PUSTAKA}

Bartlett, Brian. (2012). The Effect of Corporate Sustainability Reporting on Firm Valuation. CMC Senior Theses, 489.

Burhan, A. \& Wiwin, R. (2012). The Impact of Sustainability Reporting on Company Performance. Journal of Economics, Business, and Accountancy Ventura, 15(2).

Cahyandito, F. (2010). Pembangunan Berkelanjutan, Ekonomi dan Ekologi. Sustainability Comminication dan Sustainability Reporting. Jurnal Bisnis dan Manajemen, 5(1)

Deegan, Craig (2004). Financial Accounting Theory. The McGraw-Hill Companies, Inc.

Donaldson, Thomas and Lee E. Preston (1995). The Stakeholder Theory of the Corporation: Concepts, Evidence, and Implications. The Academy of Management Review, 20(1).

Djajadikerta, H.G. \& Trireksani, T. (2012). Corporate Social and Environmental Disclosure by Indonesian Listed Companies on Their Corporate Web Sites. Journal of applied accounting research, 13(1).

Ernst \& Young Global Limited (2013). Value of Sustainability Reporting. A study by Ernst \& Young LLP and the Boston College Center for Corporate Citizenship.

Elkington, J. (1997). Cannibals with Forks: The Triple Bottom Line of 21st Century. Business Oxford: Capstone Publishing Ltd.

Ghozali, I. \& Chariri, A. (2007). Teori Akuntansi. Semarang: Badan Penerbit Universitas Diponegoro

Global Reporting Initiative. (2011). Sustainability Reporting Guidelines, Version 3.1.

http://www.investor.co.id/home/menjaga-kesinambungan/60188, Menjaga Kesinambungan, Investor Daily Indonesia. Diakses 7 September 2013.

Kocmanova, A. \& Docekalova, M. (2011). Corporate Sustainability: Environmental, Social, Economic and Corporate Performance. Acta Universitatis Agriculturae Et Silviculturae Et Silviculturae Mendelianae Brunensis, Vol LIX Number 11. 
Kocmanova, A., Nemecek, P. \& Docekalova, M. (2012). Environmental, Social and Corporate Governance (ESG) Key Performance Indicators for Sustainable Reporting. The $7^{\text {th }}$ International Scientific Conference Business and Management 2012.

http://www.group100.com.au/publications/kpmg_g 100_SustainabilityRep200805.pdf, Sustainability repoting: A guide, KPMG International Cooperative. (2008). Diakses 19 Oktober 2013

Laan, S. (2009). The Role of Theory in Explaining Motivation for Corporate Social Disclosures: Voluntary Disclosures vs 'Solicited' Disclosures. Australasian Accounting Business and Finance Journal, 3(4)

Laplume, A., Sonpar, K., \& Litz, R. (2008). Stakeholder Theory: Reviewing a Theory That Moves Us. Journal of Management, 34(6)

Movassaghi, H. \& Bramhandkar, A. (2012). Sustainability Strategies of Leading Global Firms and Their Financial Performance: A Comparative Case Based Analysis. Journal of Applied Business and Economics, 13(5)

Ngwakwe, C. (2008). Environmental Responsibility and Firm Performance: Evidence from Nigeria. Proceeding of World Academy of Science, Engineering and Technology.

http://swa.co.id/listed-articles/pengungkapanintangible-asset-dan-apresiasi-stakeholder, Pengungkapan Intangible Asset dan Apresiasi Stakeholder. Diakses 27 Desember 2013.

Reddy, K. \& Gordon, L.W. (2010). The Effect of Sustainability Reporting on Financial Performance: An Empirical Study Using Listed Companies. Journal of Asia Entrepreneurship and Sustainability, 6(2).
Robert, K. \& David N. (2004), Strategy Maps: Converting Intangible Assets into Tangible Outcomes, First Edition, Harvard Business School Press

Ross, S., Westerfield, R., \& Jordan, B. (2003). Fundamental of Corporate Finance, Sixth Edition, Singapore: McGraw-Hill Book Company.

Siew, R., Balatbat, M., \& Carmichael, D. (2013). The Relationship Between Sustainability Practices and Financial Performance of Construction Companies, Smart and Sustainable Built Environment, 2(1)

Soelistyoningrum, J. N. 2011. Pengaruh Sustainability Report Terhadap Kinerja Keuangan (Studi Empiris pada Perusahaan yang Terdaftar Dalam Bursa Efek Indonesia). Semarang: Universitas Diponegoro.

Tomo, O. (2011). Annual Study of Intangible Asset and Market Value. The Intellectual Capital Merchant Bank Firm.

Weber, O., Koellner, T., Habegger, D., Steffensen, H., \& Ohnemus, P. (2005). The Relation Between Sustainability Performance and Financial Performance of Firms. GOE Report, 5-2005.

Welter, K. A. (2011). A Study of Publicly-Held U.S. Corporations on The Effects of Sustainability Measures on Financial Performance, Utilizing A Modified Regression Discontinuity Model. from Lawrence Technological University, http://unishop.uow.edu.au/book/a-study-ofpublicly-held-us-corporations-on-the-effects-ofsustainability-measures-on-financial-performance-utilizing-a-modified-regression-discontinuity-model.do, Diakses 24 September 2013. 